\title{
Occurrence of Drosophilids in the Pernambuco's coastal region (years 2000-2001) and the Frequency of chromosomal inversions found in Drosophila malerkotliana.
}

\author{
Pierre Teodósio Félix $^{1 *}$, José Ferreira dos Santos ${ }^{2}$ \\ 1. Laboratory of Population Genetics and Computational Evolutionary Biology - LaBECom, UNIVISA, Vitória de \\ Santo Antão, Pernambuco, Brazil. \\ *Corresponding author/ Contact: pierrefelix@ univisa.edu.br \\ 2. Laboratório de Genética de Microrganismos Departamento de Genética, Universidade Federal de Pernambuco. \\ Av. Morais Rego S/N. Cidade universitária, 50732-970, Recife (PE), Brasil \\ e-mail: recifer@npd.ufpe.br
}

Keywords: Drosophilids, chromosomal inversions, Drosophila malerkotliana, Polytene chromosome.

\begin{abstract}
Drosophilids were collected in the campus of UFPE (Recife), Rio Doce (Olinda), Vila Velha (Itamaracá), Parque de dois Irmãos (Recife) and Charles Darwin Ecological Refuge (Igarassu), in the years 2000 and 2001, seeking to establish the frequency of occurrence of the various species of the genus Drosophila. In these collections, D. malerkotliana occurred in an average frequency of $64 \%$, followed by $D$. melanogaster, with an average frequency of $23 \%$. The frequency of $D$. malerkotliana was higher than that of $D$. melanogaster in localities with high and medium degree of urbanization. Despite the great distance from the distribution center of the species (Africa), $D$. malerkotliana presented high polymorphism of chromosomal inversions. In the locality of Rio Doce, inversions In(IIL)24B-39A and In(IIL)21-25, occurred with frequencies of $18.5 \%$ and $100 \%$, respectively, while inversion In(IIIR)84-88B occurred with a frequency of $100 \%$. In the population of campus UFPE (Recife), also with high urbanization, two inversions were found, In(IIIR)93C-94A and In(IIIL)64A-72A with frequencies of 37.1 and $60 \%$, respectively. In the population of The Parque de Dois Irmãos (Recife), with medium urbanization, four inversions were visualized: In(IIIL)70C-73B (66\%); In(IIIR)93C-94A (52\%); In(IIL)24B-39A (33\%); and
\end{abstract}


In(IIR)50B-51A (33\%). In the population of the Charles Darwin Ecological Refuge (Igarassu), of low urbanization, only the inversion In(IIIR)100A-98B(?) was found. -88(?), with $100 \%$ frequency. These data suggest that the polymorphism of inversions is higher in localities with greater urbanization, possibly due to the longer colonization time, which allowed the accumulation of genetic variations.

\section{Introduction}

Drosophila malerkotliana is a species of sub cosmopolitan distribution that has been highlighted by its easy adaptation in the colonization of new environments, a high rate of occurrence and recent dispersion, as a consequence of human activity (LEMEUNIER et al., 1986). Originally from Africa, D. malerkotliana is currently colonizing Brazil in the North-South direction, having been registered in the country for the first time in the 1970s in the Northeast (VALE and SENE, 1980) and in the Amazon in the 1980s (MORAIS et al., 1995). The Southern limit of your most recently recorded distribution is Santa Catarina (from TONI, 1998). The high invasive power of this species is probably determining major ecological changes in the Brazilian fauna of Drosophila, by the displacement or substitution of native or previously established species (NASCIMENTO, 2000).

In regions of Latin America, such as the Caribbean, this species is already among the dominant ones in the drosophilid guild (MORAIS et al., 1995). In the State of Pernambuco, D. malerkotliana occurs at high relative frequencies until 1999, associated with a large number of paracentric inversions and at least one pericentric inversion complex (NASCIMENTO, 2000). In this work, the frequencies of drosophilid species were recorded, as well as the inversions that occur in the polythenic arms of D. malerkotliana of four localities of the coastal region of the State of Pernambuco were identified and quantified. In addition, a link was established between the chromosomal inversion polymorphism and the invasive potential of the species, based on the frequency of occurrence of the species in the Pernambuco coast. 


\section{Material and Methods}

\section{Species collection and identification}

Drosophilids were collected in different locations in the coastal region of the State of Pernambuco, with different degrees of urbanization. The collection sites with a marked level of urbanization were two localities within the Greater Recife region, the UFPE Campus, within the City of Recife and Rio Doce, a neighborhood in the municipality of Olinda. In these localities there is a large number of buildings, without preserved native vegetation. From the localities with medium level of urbanization were chosen the Parque de dois irmãos, which even being a forest reserve with good preservation of native vegetation (secondary forest spot), is located within the city of Recife and surrounded by environments with high levels of urbanization. The locations chosen with a low level of urbanization were the Charles Darwin Ecological Refuge, a reserve of secondary Atlantic forest, well preserved in recent decades, located in the municipality of Igarassu, and Vila Velha, in Itamaracá (Figure 1). The samples were collected during the years 2000 and 2001, following the availability of adult individuals, which varies according to climatic conditions.

The collections were made using banana baits, taken to the field and distributed in cylindrical glass tubes with a capacity of $150 \mathrm{ml}$, or by collecting eggs and larvae in fruits in fermentation. A stereoscopic microscope was used for taxonomic observation and identification of adult individuals, according to identification key (FREIRE-MAIA and PAVAN, 1949). For differentiation between $D$. melanogaster and D. malerkotliana, the absence of tarsal comb was considered in males of the latter species (VAL and SENE, 1980). 


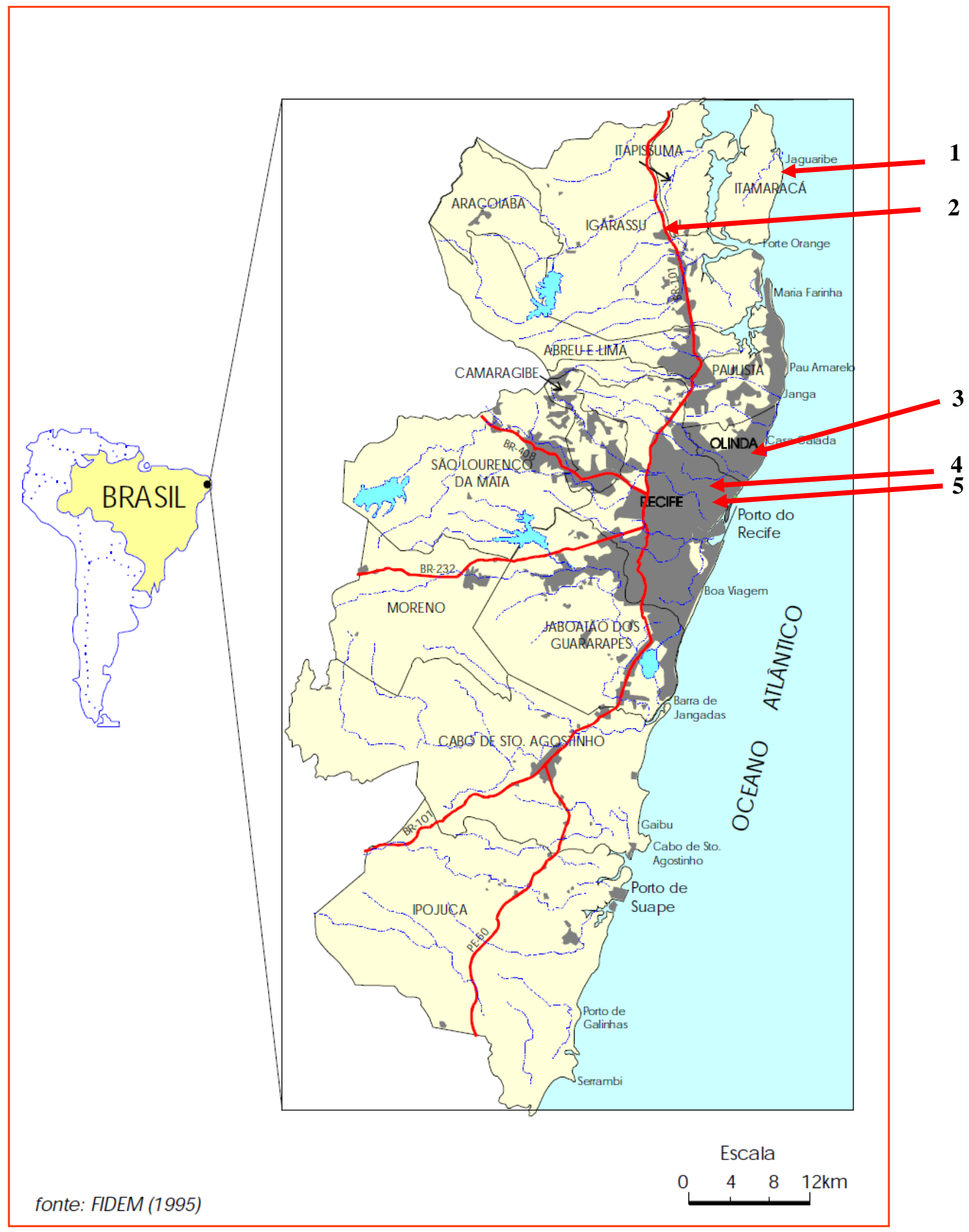

Figure 1. Map of the Coastal Region of Pernambuco, indicating the collection sites: Vila Velha in Itamaracá (1); Charles Darwin Ecological Refuge in Igarassu (2); Rio Doce in Olinda (3); UFPE Campus (4) and Parque de dois irmãos in Recife (5). Map adapted by FIDEM (1995). 


\section{Cytological preparations}

The females of D.malerkotliana born from each population were individually peaked to establish iso-females in glass containing culture medium prepared with corn flour, fresh organic yeast and banana, being daily peaked and fed with yeast. Sixty-five iso-females strains from campus UFPE, 23 from Rio Doce, 12 from parque de dois irmãos and 19 from Charles Darwin Ecological Refuge were analyzed.

The slides of $D$. malerkotliana polythenic chromosomes were prepared by crushing the dissected salivary glands of third stage larvae, fixed with a solution of acetic acid, water and lactic acid, in a 3:2:1 ratio. The material was stained with $1 \%$ aceto lactic orcein ( $1 \mathrm{~g}$ of orcein, $45 \mathrm{ml}$ of acetic acid, $25 \mathrm{ml}$ of lactic acid $85 \%$ and $30 \mathrm{ml}$ of distilled water), according to ASHBURNER (1967). After the best points were scored, the chromosomes were photographed under Leica Microscope in increase of 100 X 1.25 with Kodak's TMAX Iso 100 film. The breaking points of the inversions were established by comparison with the photomap made by FÉLIX et al. (2002).

\section{Results}

In the period studied D. malerkotliana was the most represented species, reaching $66 \%$ in 2000 and $61 \%$ in 2001, followed by D. melanogaster, with frequencies of 25 and $21 \%$ in those same years. The frequency, around $10 \%$, also draws attention to the frequency of another invasive drosophilid, Zaprionus indianus (Figure 2).

Both in 2000 and 2001, the frequency of occurrence of D. malerkotliana was higher than that of D. melanogaster in the locations with high urbanization (UFPE Campus, Rio Doce) and medium (Parque Dois Irmãos), and the opposite is observed in the low urbanization locations (Vila Velha, Charles Darwin Ecological Refuge), as can be seen in Table 1.

The frequencies of chromosomal inversions of the populations of UFPE campus, Rio Doce, Parque de dois Irmãos and Charles Darwin Ecological Refuge were determined (Table 2). In the population of the UFPE campus, two inversions were observed, one in the IIIR arm, In(IIIR)93C- 
94A with a frequency of $37.1 \%$, and one in the IIIL arm, In(IIIL)64A-72A with a frequency of $60 \%$. In the population of Rio Doce, three inversions were identified, two of them in the IIL arm, In(IIL)24B-39A with a frequency of $18.5 \%$ and In(IIL)21-25 with 100\%, and one in the IIIR arm, In(IIIR) $84-88 B$, with a frequency of $100 \%$. In the population of The Parque de dois Irmãos, four inversions were found, one of them in the IIIL arm, In(3L)70C-73B with frequency of $66 \%$, another in the IIIR arm, $\operatorname{In}(3 \mathrm{R}) 93 \mathrm{C}-94 \mathrm{~A}$ with frequency of $52 \%$, another in the IIL arm, $\operatorname{In}(2 \mathrm{~L}) 24 \mathrm{~B}-39 \mathrm{~A}$ with frequency of $33 \%$ and one in the IIR arm, $\operatorname{In}(2 \mathrm{R}) 50 \mathrm{~B}-51 \mathrm{~A}$ with frequency of $33 \%$. In the population of the Charles Darwin Ecological Refuge, a single inversion was found in the IIIR arm, In(3R)100A-98B? -88? 100\% frequency. 


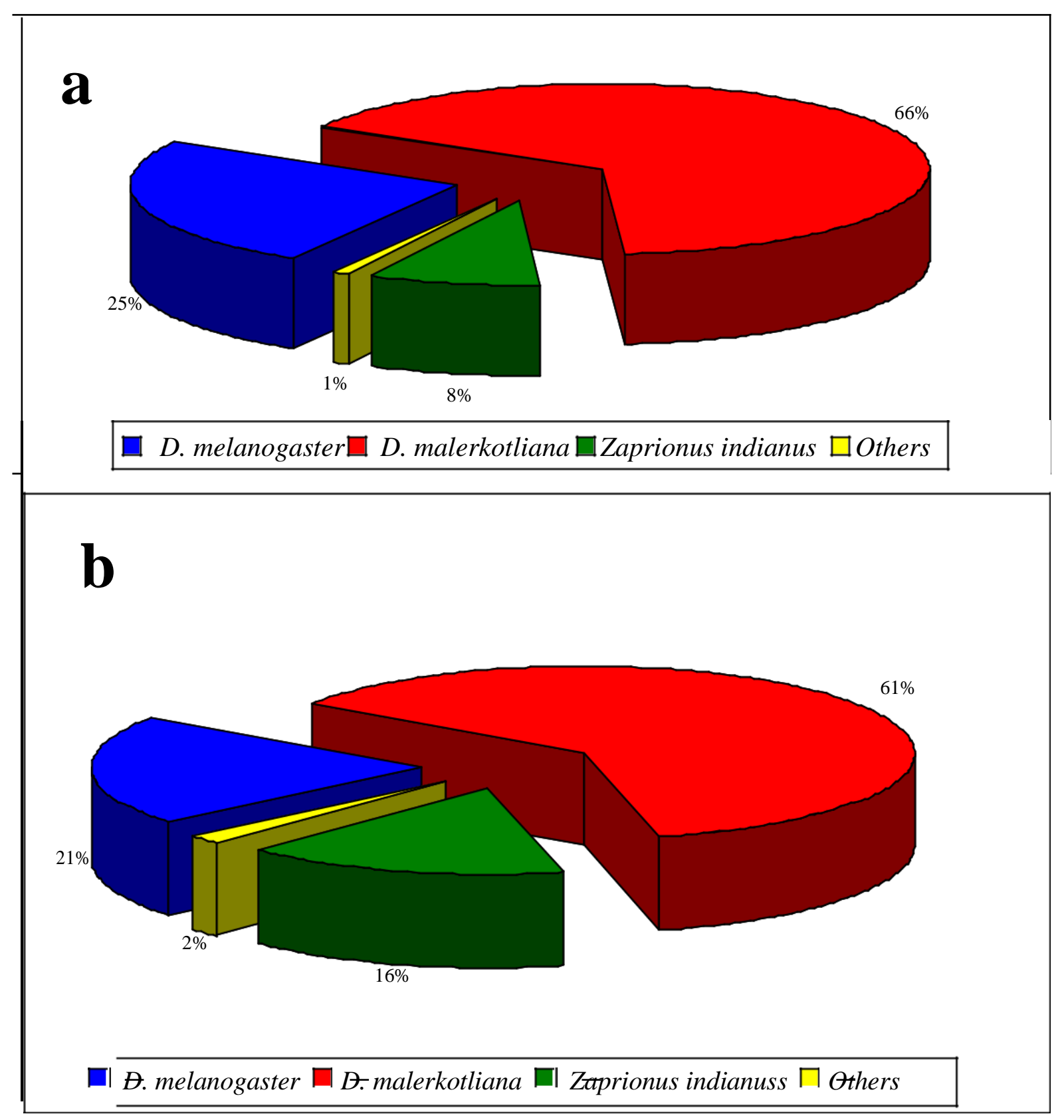

Figure 2. Frequency of drosophilids collected in the years 2000 (a) and 2001 (b) in the coastal region of Pernambuco, as shown in the map in Figure 1. Note the high frequencies of the invasive species D. malerkotliana and Zaprionus indianus. 
Table 1. Frequency of Drosophilids occurrence in the in the Pernambuco's coastal region (years 20002001).

\begin{tabular}{ccccccccc|cccccc}
\hline \multicolumn{1}{c}{ Locality } & \multicolumn{10}{c}{ Campus-UFPE (Recife) } \\
\hline Year & \multicolumn{10}{c}{ 2000 } \\
Species & Apr & Jun & Sep & Oct & Nov & Dec & $\%$ & Jan & Mar & Apr & May & Jul & $\%$ \\
D.melanogaster & 1634 & 751 & - & 16 & 95 & 81 & 25 & - & - & - & - & 217 & 40 \\
D. malerkotliana & 2021 & 1756 & - & 779 & 861 & 1079 & 65 & - & - & - & & 287 & 52 \\
Z. indianus & 367 & 392 & - & 18 & 5 & 30 & 8 & - & - & - & - & 37 & 6 \\
D. willistoni & 45 & 0 & - & 0 & 3 & 0 & 0,4 & - & - & - & - & 0 & 0 \\
D. guarani & 0 & 0 & - & 0 & 0 & 1 & 0,01 & - & - & - & - & 1 & 0 \\
D. nebulosa & 2 & 7 & - & 0 & 0 & 0 & 0,09 & - & - & - & - & 0 & 0 \\
Outras & 3 & 7 & - & 0 & 0 & 0 & 0,07 & - & - & - & - & 6 & 1 \\
\hline
\end{tabular}

\begin{tabular}{cccccccc|cccccc}
\hline Locality & \multicolumn{1}{c}{ Rio Doce (Olinda) } & \multicolumn{5}{c}{ Vila Velha (Itamaracá) } \\
\hline Year & \multicolumn{4}{c}{ 2000 } & \multicolumn{7}{c}{ 2001 } \\
Species & Apr & Jun & Sep & Oct & Nov & Dec & $\%$ & Jan & Mar & Apr & May & Jul & $\%$ \\
D.melanogaster & - & - & - & 9 & 10 & - & 6 & - & 229 & - & - & - & 36 \\
D. malerkotliana & - & - & & 86 & 119 & - & 73 & - & 54 & - & - & - & 8 \\
Z. indianus & - & - & - & 27 & 0 & - & 9 & - & 300 & - & - & - & 48 \\
D. willistoni & - & - & - & 0 & 0 & - & 0 & - & 7 & - & - & - & 1 \\
D. nebulosa & - & - & - & 0 & 0 & - & 0 & - & 30 & - & - & - & 4 \\
Outras & - & - & - & 27 & 0 & - & 9 & - & 0 & - & - & - & 0 \\
\hline
\end{tabular}

\begin{tabular}{cccccccc|cccccc}
\hline Locality & \multicolumn{10}{c}{ Dois Irmãos Park (Recife) } \\
\hline Year & \multicolumn{10}{c}{$\mathbf{2 0 0 0}$} \\
Species & Apr & Jun & Sep & Oct & Nov & Dec & $\%$ & Jan & Mar & Apr & May & Jul & $\%$ \\
D.melanogaster & - & - & - & - & - & 175 & 15 & 56 & - & - & - & - & 34 \\
D. malerkotliana & - & - & - & - & - & 814 & 72 & 84 & - & - & - & - & 51 \\
Z. indianus & - & - & - & - & - & 133 & 11 & 24 & - & - & - & - & 14 \\
D. nebulosa & - & - & - & - & - & 3 & 0 & 0 & - & - & - & - & 0 \\
\hline
\end{tabular}

\begin{tabular}{cccccccc|cccccc}
\hline Locality & \multicolumn{10}{c}{ Charles Darwin Ecological Refuge (Igarassu) } \\
\hline Year & \multicolumn{10}{c}{$\mathbf{2 0 0 0}$} \\
Species & Apr & Jun & Sep & Oct & Nov & Dec & $\%$ & Jan & Mar & Apr & May & Jul & $\%$ \\
D.melanogaster & - & - & 102 & - & - & - & 61 & - & - & 5 & 67 & - & 5 \\
D. malerkotliana & - & - & 60 & - & - & - & 35 & - & - & 821 & 440 & - & 89 \\
Z. indianus & - & - & 1 & - & - & - & 0,5 & - & - & 76 & 0 & - & 5 \\
D. guarani & - & - & 4 & - & - & - & 2 & - & - & 1 & 0 & - & 0 \\
\hline
\end{tabular}


Table 2. Frequencies of paracentric inversions in heterozygosis in the polythenic chromosomes of populations of $D$. malerkotliana from the Pernambuco's coastal region. The breakpoints of the inversions were determined based on the photomap made by FÉLIX et al (2002).

\begin{tabular}{|c|c|c|c|c|c|}
\hline Chromosomic Arms & Inversions & $\begin{array}{c}\text { Campus-UFPE } \\
\text { (Recife) }\end{array}$ & $\begin{array}{l}\text { Rio Doce } \\
\text { (Olinda) }\end{array}$ & $\begin{array}{c}\text { Charles Darwin Refuge } \\
\text { (Igarassu) }\end{array}$ & $\begin{array}{l}\text { Dois Irmãos Park } \\
\text { (Recife) }\end{array}$ \\
\hline \multirow[t]{2}{*}{ IIIR } & In(IIIR)93C-94A & $37,1 \%$ & - & - & $52,0 \%$ \\
\hline & In(IIIR)100A -98B?-88? & - & - & $100,0 \%$ & - \\
\hline \multirow[t]{2}{*}{ IIIL } & $\operatorname{In}($ IIIL) $64 \mathrm{~A}-72 \mathrm{~A}$ & $60,0 \%$ & - & - & - \\
\hline & In(IIIL)70C-73B & - & - & - & $66,0 \%$ \\
\hline IIR & In(IIR)50B-51A & - & - & - & $33,0 \%$ \\
\hline
\end{tabular}




\section{Discussion}

The species of Drosophilids from northeastern Brazil are scarcely studied, and only some species of the melanogaster and willistoni group are recorded (VAL and SENE, 1980; SENE et al., 1980; EHRMAN and POWELL, 1982). In this work, populations from five localities in the coastal region of Pernambuco were studied, seeking to relate the drosophilid fauna to the different degrees of environmental urbanization, as verified between the urban area of Porto Alegre and the area without urbanization in Rio Grande do Sul (SANTOS and VALENTE, 1990; BONORINO et al., 1993; ROHDE and VALENTE, 1996; VALIATE and VALENTE, 1996, 1997).

The largest variety of species was found in the Charles Darwin Refuge, probably due to the better ecological conditions and their relative distance (approximately $7 \mathrm{~km}$ ) from large urban centers. However, the species D. malerkotliana and D. melanogaster were more frequent in environments with medium (Parque de Dois Irmãos) and high urbanization levels (UFPE Campus and Rio Doce). Possibly, like D. melanogaster, D. malerkotliana is also preferentially distributed in a way associated with human activities (LEMEUNIER et al. 1986).

Due to its potential invader D. malerkotliana now stands out as the predominant species in the coastal region of the State of Pernambuco. Confirming the extensive alteration of the current fauna in relation to that described in the literature (VAL and SENE, 1980; SENE et al., 1980; VAL et al., 1981; EHRMAN and POWELL, 1982), found at relatively high frequency (10\%) the drosophilid Zaprionus indianus, whose presence in the State was initially recorded in 2000 (FÉLIX et al., 2001). Other species such as Drosophila kikawai, D. nebula and D. guarani had frequencies lower than $1 \%$ in the years 2000 and 2001 . Nevertheless, it was not expected to find the latter in the Northeast, because it is a species considered cold climate (VAL et al., 1981).

Numerous factors such as limitation of feeding resources and low rainfall rates may have caused changes in the drosophilid fauna in northeastern Brazil. In addition to these factors, competition between species contributed to the replacement of D. melanogaster by $D$. malerkotliana in the Northern Region (MARTINS, 1995; SANJAD, 1997) and Nordeste (NASCIMENTO, 2000) of Brazil, as also observed by VALENTE et al. (1993) and VALIATE 
and VALENTE (1996) for D. willistoni in Rio Grande do Sul. These changes in the Drosophilids fauna may have also led to important qualitative changes in the composition of the communities of other associated organisms, such as yeasts, which have a direct association with drosophilids for their dispersion (BEGON, 1982). Due to the lack of previous studies, the existing relationships derived from these changes cannot be fully evaluated.

The colonization of new environments by Drosophilids is a common phenomenon, and species substitution has been observed with a certain frequency. The invasive potential of the species and the ease of adaptation to austere environments has been attributed, by several authors, to the loss or gain of variability by selection forces. VALIATE and VALENTE (1997) observed a substitution of $D$. willistoni by $D$. paulistorum in the city of Porto Alegre, demonstrating that $D$. paulistorum has a large number of chromosomal inversions, thus increasing its variability and adaptive power. The gene arrangements contained in the inversion loops are inherited in a simple Mendelian way, passing to the descendants as a single gene (TAYLOR and POWELL, 1983). The variation in polymorphism results from the ability of species to explore different environments and plays an adaptive role for various aspects related to the survival of individuals and reproduction (SPERLICH and PFRIEM, 1986).

From the genetic point of view, inversion has as a consequence the restriction, or even total blockage of gene recombination in the inverted region. When pairing is inverted or a-synaptic, chiasm usually does not occur in this region and, when it occurs, forms chromatids with deletions and duplications, due to incorrect pairing. Evolutionarily this blockage causes some heterozygotes for inversions to be more adapt than their homozygous forms, because only the genes contained in the inversion are maintained in heterozygosis (TAYLOR and POWELL, 1983). This hypothesis is corroborated by the fact that in some populations there is a certain inversion in $100 \%$ of the individuals analyzed, such as $\operatorname{In}(3 \mathrm{R}) 84-88 \mathrm{~B}$ in the population of Rio Doce (Olinda) and In(3R)100A-98B? -88? population of the Charles Darwin Ecological Refuge (Table 2).

The populations of $D$. malerkoltiana present a high degree of polymorphism of chromosomal inversions, even though it is a species that recently invaded Brazilian territory (VAL 
and SENE, 1980). Associated with the polymorphism of male tergite coloring (NASCIMENTO, 2000), inversion polymorphism characterizes a genetic variability that can enable the species to colonize this type of colonization, since the most polymorphic populations tend to occupy large areas because they have a variety of gene arrangements that allow the occupation of a wide variety of habitats (TAYLOR and POWELL , 1983). It is worth remembering that due to the similarity of the banding pattern between the sections of the polythenic chromosomes of D. malerkotliana, it was not possible to quantify the frequencies of homozygotes for the "standard" or "inverted" arrangements.

It was found that in the low-level urbanization environment, the Charles Darwin Ecological Refuge in Igarassu, the population did not present high polymorphism of chromosomal inversions. However, the inversion $\operatorname{In}(3 \mathrm{R}) 100 \mathrm{~A}-98 \mathrm{~B} ?-88$ ? it was found in all the polythenic nuclei observed, showing conservation in the karyotypic constitution, possibly due to the recent establishment of the population. The populations of localities with a high level of urbanization, such as those of the UFPE Campus and Rio Doce, presented together five chromosomal inversions, present in all 4 autosomal arms. However, one of the inversions, In(2L)24B-39A, is common to the population of Parque Dois Irmãos, which is an environment with an average level of urbanization. Based on these observations, it is suggested that there was a decrease in the polymorphism of the chromosomal inversions of the populations, in relation to the increase in the level of urbanization of the localities.

\section{References}

Ashburner, M. 1967. Patterns of puffing activity in the salivary gland chromosomes of Drosophila. I. Autosomal puffing patterns in a laboratory stock of D. Melanogaster. Chromosoma, 27: 477-63. 
Begon, M. 1982. Yeast and Drosophila, In: Ashburner, M.; Carson, H. L.; Thompson, Jr., J.N. (Eds.), The Genetics and Biology of Drosophila, Academic Press, London, Vol. 3b, p. 345-384.

Bonorino, C. B. C.; Valente, V. L. S; Callegari-Jacques, M. 1993. Urbanization and chromosomal polymorphism of Drosophila nebulosa. Braz. J. Genet., 16: 59-71.

De Toni, D. C. 1998. Estudo de comunidade de Drosophila em regiões de Mata Atlântica do Continente e de ilhas de Santa Catarina e variabilidade cromossômica de Drosophila polymorpha. Dissertação de Mestrado, UFRGS, Porto Alegre.

Ehrman, L; Powell, J. R. 1982. The Drosophila willistoni species group. In: Ashburner, M; Carson, H.L.; Thompson, Jr., J.N. (Eds.), The Genetics and Biology of Drosophila, Academic Press, London, Vol. 3b, p. 345-384.

Félix, P. T.; Rieger, T. T.; Santos, J. F. 2001. Polimorfismo de inversão em cromossomos politênicos de populações naturais de Drosophila malerkotliana no Estado de Pernambuco. Anais do $47^{\circ}$ Cong. Nac. Genética.pp704.

FIDEM.1995. Mapa da Cobertura Vegetal da Região Metropolitana do Recife, escala 1:100.00 Recife.

Freire-Maia, N.; Pavan, C. 1949. Introdução ao estudo da Drosófila. Cultus, 1(5):1-77 pp.

Jha, A. P.; Rahman, S. M. Z. 1973. On crossing between Drosophila bipectinata and Drosophila malerkotliana. Cytologia, 38: p.425-436. 
Lemeunier, F.; David, J. R.; Tsacas, L.; Ashburner, M. 1986. The melanogaster species group. In: Ashburner, M., Carson, H.L.; Thompson, Jr. J. N. (Eds), The Genetics and Biology of Drosophila, Academic Press, London.3:147-256.

Martins, M. 1985. Influência da modificação do habitat sobre a diversidade e abundância de Drosophila (Díptera, Drosophilidae) em uma floresta tropical da Amazônia Central. Dissertação de Mestrado, UNICAMP, Campinas. 185 pp.

Martins, M. 1995. Drosófilas e outros insetos associados a frutos de Parahancornia amapa sobre o solo da floresta. Tese de Doutorado, UNICAMP, Campinas.176 pp.

Morais, P. B.; Martins, M.B.; Klaczko, L.B.; Mendonça-Hagler, L.C.; Hagler, A. N. 1995. Yest succession in the Amazon fruit Parahancornia amapa as resource partioning among Drosophila spp. App.Envir.Microb. 61: 4251-4252.

Nascimento, A. C. C. 2000. Drosofilídios da região litorânea de Pernambuco e cromossomos politênicos de Drosophila malerkotliana. Monografia de Bacharelado. UFRPE. Recife. 38 pp.

Rohde,C.; Valente, V.L.S. 1996. Citological maps and chromosomal polymorphism of Drosophila polymorpha and Drosophila cardinoides. Braz.J.Genet., 19:27-32.

Sanjad, N. 1997. Mosca reduz biodiversidade: Drosophila invasora provoca desaparecimento de espécies nativas da floresta amazônica. Ciência Hoje, 18, p. 66. 
Santos, R.A.; Valente, V. L. S. 1990. On the occurrence of Drosophila paulistorum. Dobzansky

\& Pavan (Diptera, Drosophilidae) in urban environment: Ecological observation. Evol. Biol., 4: $253-268$.

Sene, F.M; Val, F.C.; Vilela, C. R.; Pereira, M. A. Q. R. 1980. Preliminary data on the geographical distribution of Drosophila species within morfoclimatic domains of Brazil. Papéis Avulsos de Zoologia, 33: 315-326.

Sorsa, V. 1988. Chromosome maps of Drosophila. Vol.I. CRC Press Inc., Boca Raton.200 pp.

Sperlich, D; Pfriem, P. 1986. Chromosomal polymorphism in natural and experimental population. In: ASHBURNER, M.; CARSON, H.L. and THOMPSON, Jr., J.N. (Eds.), The genetics and biology of Drosophila. Academy, New York, vol. 3c., p. 257-309.

Taylor, C. E.; Powell, J. R. 1983. Population struture of Drosophila: genetics and ecology. In: ASHBURNER, M.; CARSON, H. L. and THOMPSON, Jr., J. N. (Eds.), The genetics and biology of Drosophila. Academic Press, New York, V. 3d, p. 29-59.

Val, F. C.; Sene, F. M. 1980. A newly introduced Drosophila species in Brazil (Diptera, Drosophilidae). Papéis Avulsos de Zoologia, 33: 293-298.

Val, F. C.; Vilela, C. R.; Marques, M. D. 1981. Drosophilidae of the Neotropical Region. In: Ashburner, M; Carson, H.L.; Thompson, Jr., J.N(Eds.), The Genetics and Biology of Drosophila, Academic Press, London, Vol. 3a, p. 123-168. 
Valente, V. S. V.; Ruszczyk, A.; Santos, R. A. 1993. Chromosomal polimorphism in urban Drosophila willistoni. Braz. J. Genet., 16: 307-319.

Valiate, V. H.; Valente, V. L. S. 1996. Observations on ecological parameters of urban populations of Drosophila paulistorum Dobzansky \& Pavan (Diptera, Drosophilidae). Rev. Bras. Entom., 40: 225-231.

Valiate, V. H.; Valente, V. L. S. 1997. Chromosomal polimorphism in urban populations of Drosophila paulistorum. Braz. J. Genet., 20: 567-581. 
bioRxiv preprint doi: https://doi.org/10.1101/2020.08.05.238634; this version posted August 6, 2020. The copyright holder for this preprint (which was not certified by peer review) is the author/funder, who has granted bioRxiv a license to display the preprint in perpetuity. It is made available under aCC-BY-ND 4.0 International license.

\section{Attachments}

$\mathbf{a}$

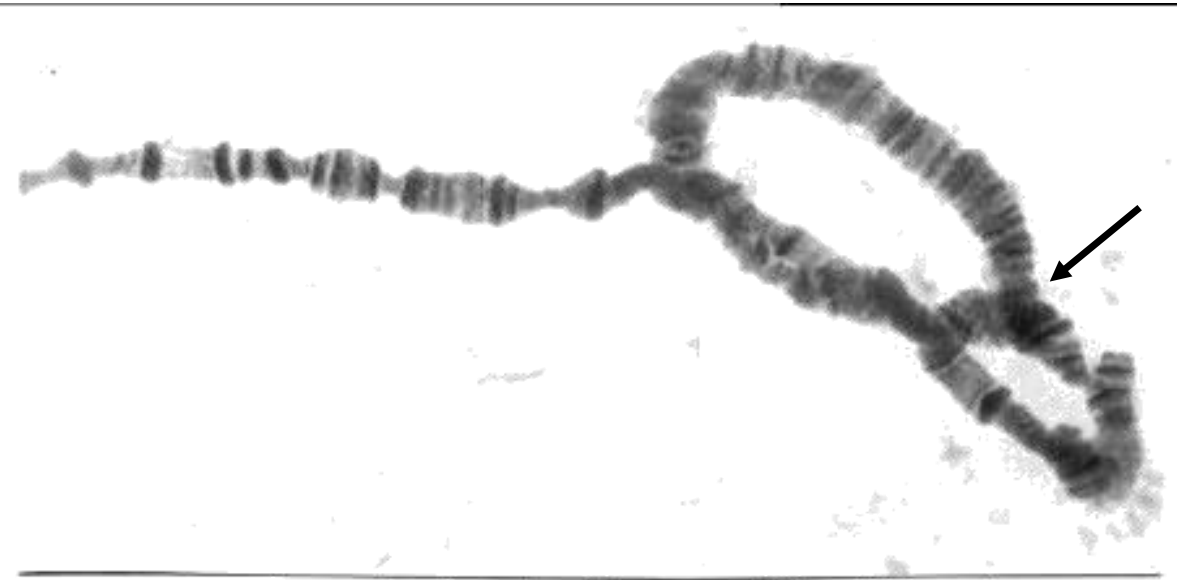

b

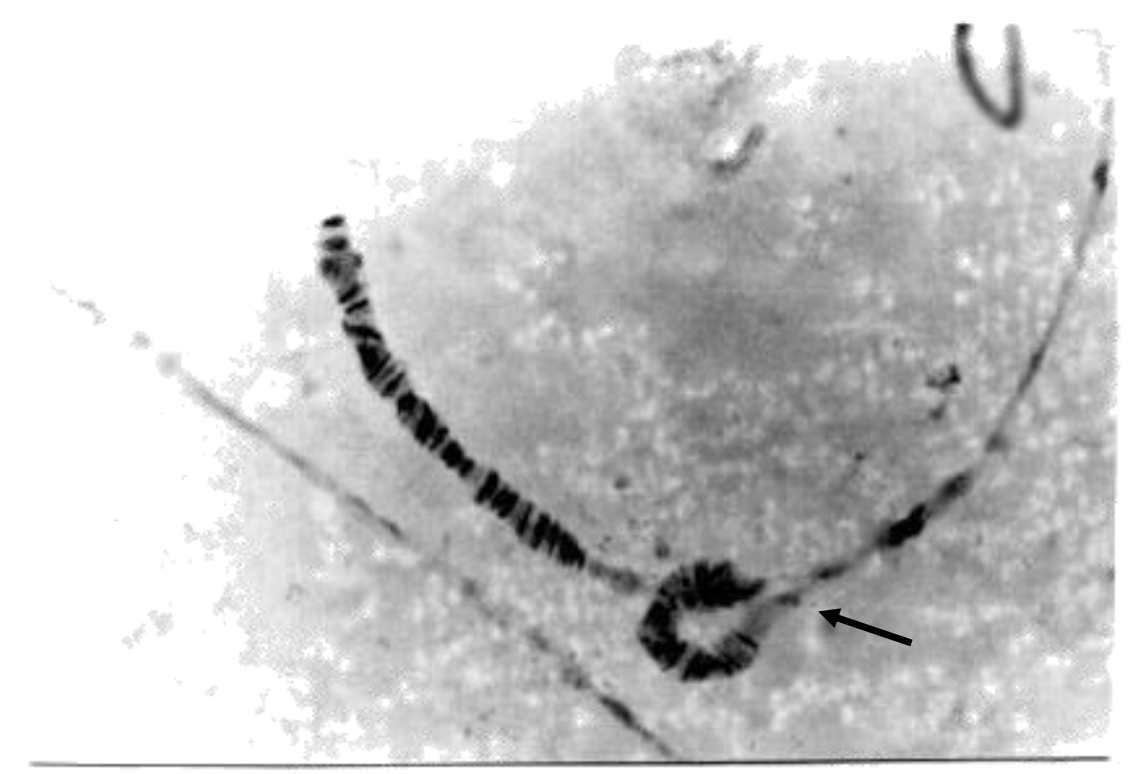

C

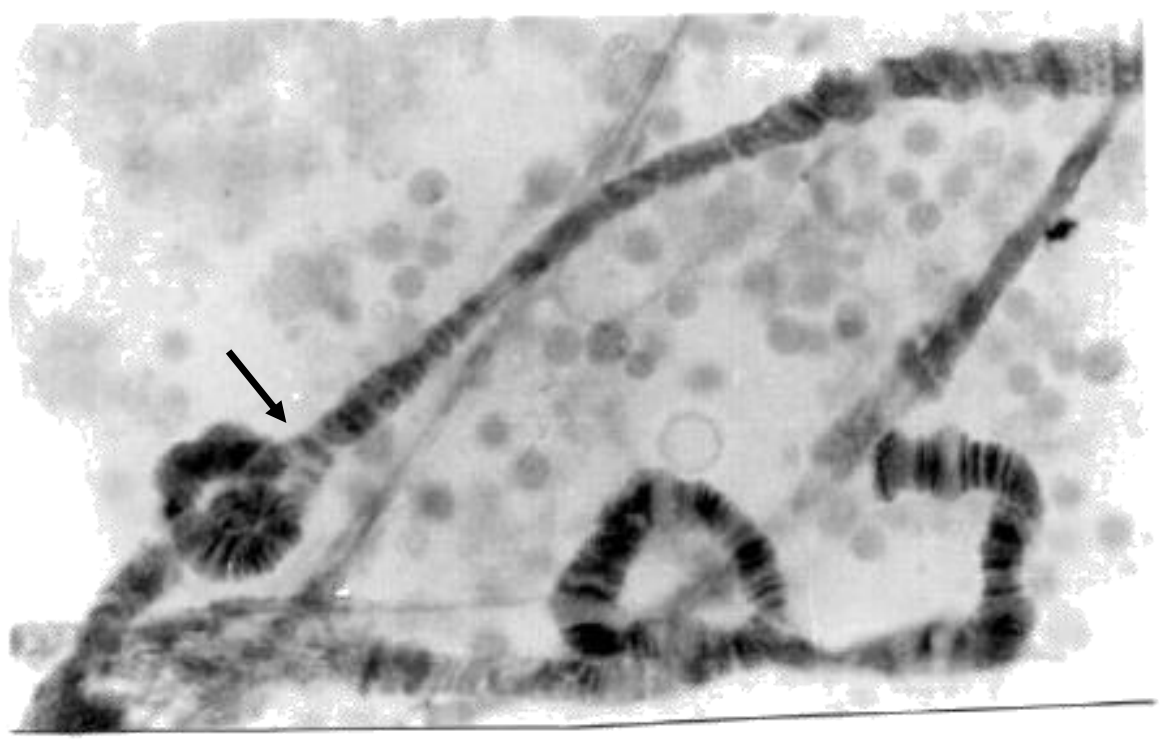

Figure 2. Chromosomal inversions in the IIIR arm of D. malerkotliana. In(IIIR)100A-98B?-88?, with a frequency of $100 \%$ of the population of the Charles Darwin Ecological Refuge (a). In(IIIR)93C-94A, with frequency of $37.1 \%$ of the population of Campus-UFPE (b). In(IIIR)84$88 \mathrm{~B}$, with frequency of $100 \%$ of the population of Rio Doce-Olinda (c). 
bioRxiv preprint doi: https://doi.org/10.1101/2020.08.05.238634; this version posted August 6, 2020. The copyright holder for this preprint (which was not certified by peer review) is the author/funder, who has granted bioRxiv a license to display the preprint in perpetuity. It is made available under aCC-BY-ND 4.0 International license.

\section{a}
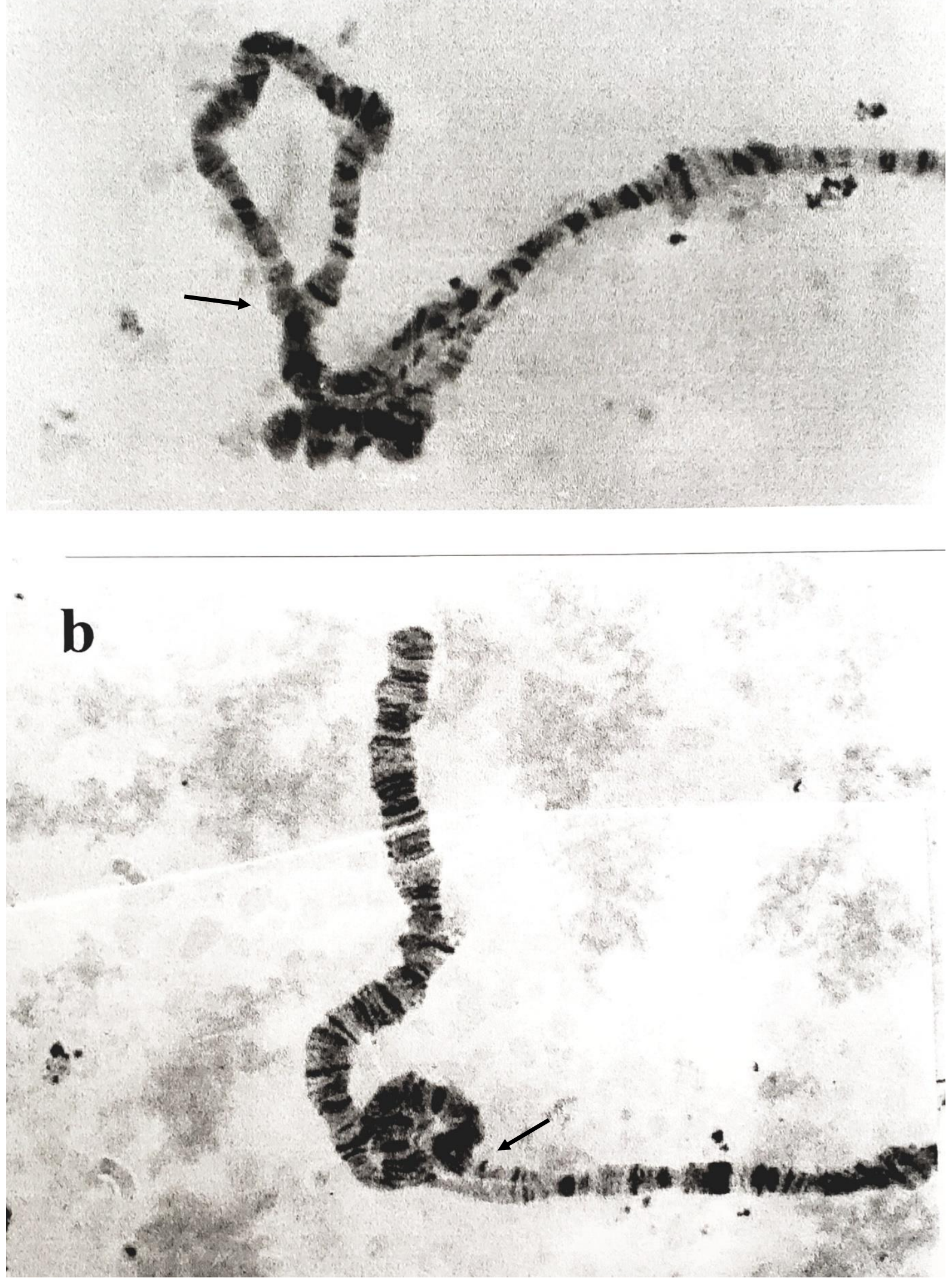

Figure 3. Chromosomal inversions in the IIIL arm of D. malerkotliana. In(IIIL)72A$64 \mathrm{~A}$, with frequency of $60 \%$ of the population of Campus-UFPE (a). In(IIIL)70C$73 \mathrm{~B}$, with a frequency of $66 \%$ of the Dois Irmãos Park (b). 
bioRxiv preprint doi: https://doi.org/10.1101/2020.08.05.238634; this version posted August 6, 2020. The copyright holder for this preprint (which was not certified by peer review) is the author/funder, who has granted bioRxiv a license to display the preprint in perpetuity. It is made available under aCC-BY-ND 4.0 International license.

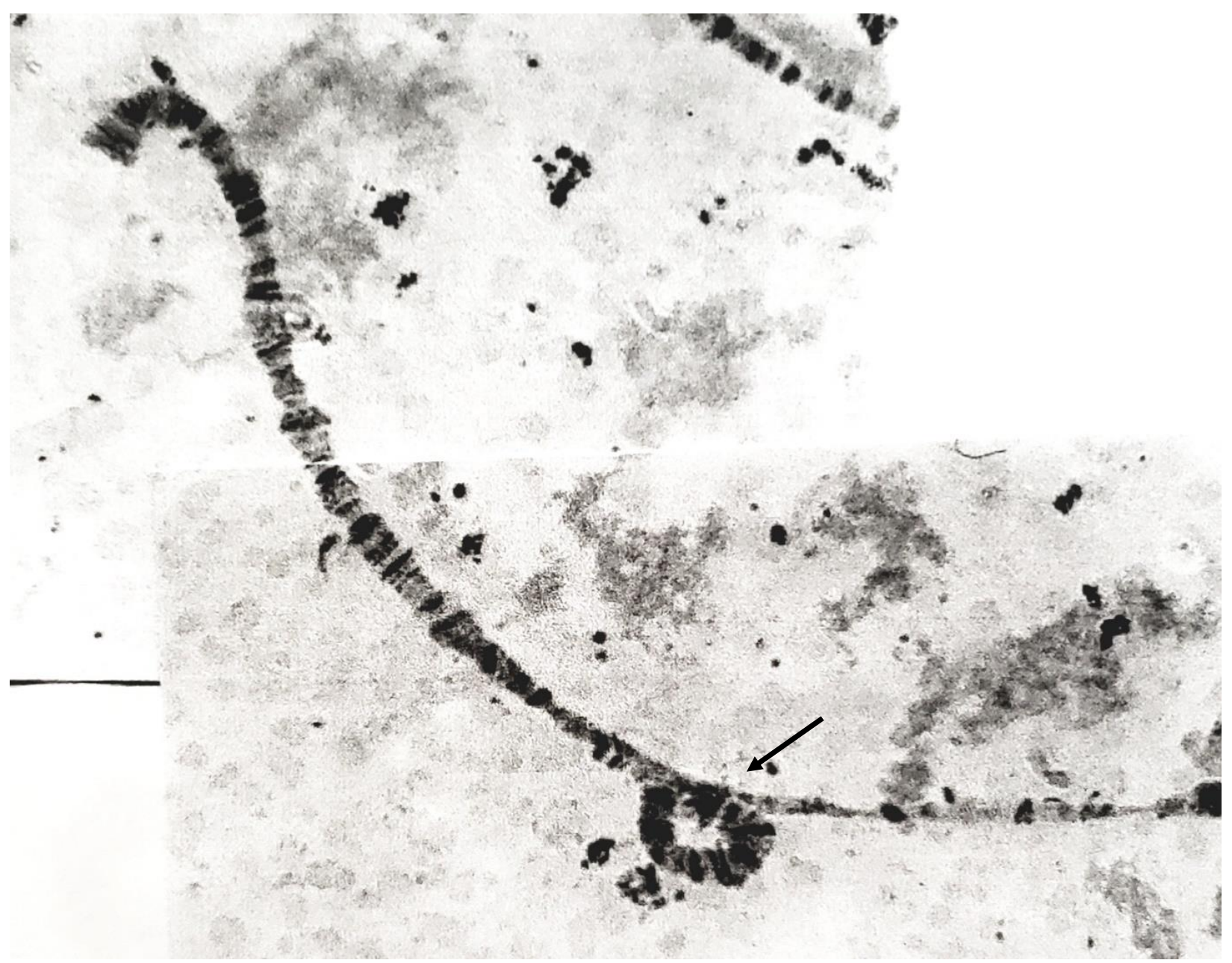

Figure 4. Chromosomal inversion in the IIR-In(IIR)50B-51A arm, with a frequency of $33 \%$ in the population of $D$. malerkotliana of Dois irmãos Park. 
bioRxiv preprint doi: https://doi.org/10.1101/2020.08.05.238634; this version posted August 6, 2020. The copyright holder for this preprint (which was not certified by peer review) is the author/funder, who has granted bioRxiv a license to display the preprint in perpetuity. It is made available under aCC-BY-ND 4.0 International license.
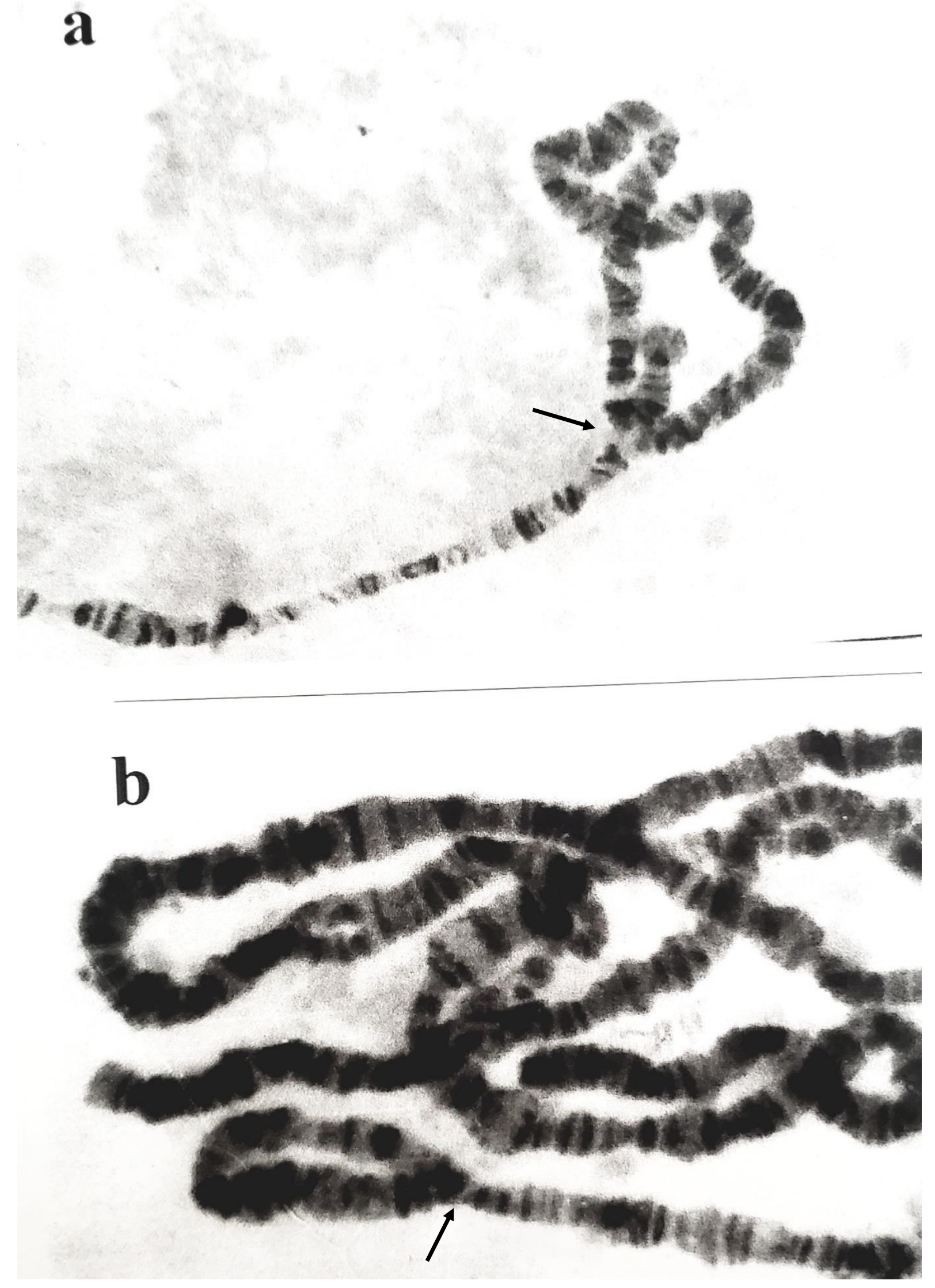

Figure 5. Chromosomal inversion in the IIL arm of D. malerkotliana. In (IIL)24B-39A, with frequency of $18.5 \%$ of the population of Rio Doce, and with frequency of $33 \%$ in the population of Dois Irmãos Park (a). In(IIL)21-25 with a frequency of 100\% in the population of Rio Doce (b). 